Sustaining Liberal Democracy 
Also by John Barry

RETHINKING GREEN POLITICS: Nature, Virtue and Progress

ENVIRONMENT AND SOCIAL THEORY

CITIZENSHIP, SUSTAINABILITY AND ENVIRONMENTAL RESEARCH:

Q Methodology and Local Exchange Trading Systems (with John Proops)

Also by Marcel Wissenburg

CIVIL SOCIETY AND CIVIC POLITICS (editor)

EUROPEAN DISCOURSES ON ENVIRONMENTAL POLICY (co-editor with Gökhan Orhan and Ute Collier)

GREEN LIBERALISM: The Free and the Green Society

IMPERFECTION AND IMPARTIALITY: A Liberal Theory of Social Justice 


\section{Sustaining Liberal Democracy}

\section{Ecological Challenges and Opportunities}

Edited by

John Barry

Reader

School of Politics

The Queen's University of Belfast

Northern Ireland

and

Marcel Wissenburg

Lecturer in Political Theory and Philosophy of Policy Sciences Nijmegen Centre for Business, Environment and Government University of Nijmegen

The Netherlands

Foreword by Andrew Dobson 


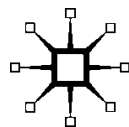

Editorial matter, selection and Chapter 1 (c) John Barry and Marcel Wissenburg 2001

Foreword @ Andrew Dobson 2001

Chapter 4 (C) John Barry 2001

Chapter 12 (C) Marcel Wissenburg 2001

Chapter 13 ๑ John Barry, Marcel Wissenburg and Marius de Geus 2001

Chapters 2, 3, 5-11 @ Palgrave Publishers Ltd 2001

Softcover reprint of the hardcover 1st edition 2001 978-0-333-91981-1

All rights reserved. No reproduction, copy or transmission of this publication may be made without written permission.

No paragraph of this publication may be reproduced, copied or transmitted save with written permission or in accordance with the provisions of the Copyright, Designs and Patents Act 1988, or under the terms of any licence permitting limited copying issued by the Copyright Licensing Agency, 90 Tottenham Court Road, London W1P OLP.

Any person who does any unauthorised act in relation to this publication may be liable to criminal prosecution and civil claims for damages.

The authors have asserted their rights to be identified as the authors of this work in accordance with the Copyright, Designs and Patents Act 1988.

First published 2001 by

PALGRAVE

Houndmills, Basingstoke, Hampshire RG21 6XS and

175 Fifth Avenue, New York, N. Y. 10010

Companies and representatives throughout the world

PALGRAVE is the new global academic imprint of

St. Martin's Press LLC Scholarly and Reference Division and

Palgrave Publishers Ltd (formerly Macmillan Press Ltd).

ISBN 978-1-349-42422-1 ISBN 978-1-4039-0079-1 (eBook)

DOI 10.1057/9781403900791

This book is printed on paper suitable for recycling and made from fully managed and sustained forest sources.

A catalogue record for this book is available from the British Library.

Library of Congress Cataloging-in-Publication Data

Sustaining liberal democracy : ecological challenges and opportunities / edited by John Barry and Marcel Wissenburg ; foreword by Andrew Dobson.

p. cm.

Includes bibliographical references and index.

1. Political ecology. 2. Liberalism. 3. Sustainable development-Political aspects. 4. Environmentalism-Political aspects.

5. Human ecology—Political aspects. I. Barry, John, 1966II. Wissenburg, M. L. J. (Marcel L. J.)

JA75.8 .S87 2000

320.51 '3-dc21

00-066888

$\begin{array}{llllllllll}10 & 9 & 8 & 7 & 6 & 5 & 4 & 3 & 2 & 1\end{array}$

$\begin{array}{llllllllll}10 & 09 & 08 & 07 & 06 & 05 & 04 & 03 & 02 & 01\end{array}$ 


\section{Contents}

Foreword by Andrew Dobson vii

The Contributors $\quad \mathrm{xi}$

1 Introduction

John Barry and Marcel Wissenburg 1

\section{Part I Liberalism and Sustainability}

2 Sustainability, Liberal Democracy, Liberalism

Marius de Geus

3 Ecological Sustainability: a Private Case of Social Justice?

Gayil Talshir

\section{Part II Reform and Change}

4 Greening Liberal Democracy: Practice, Theory and Political Economy

John Barry

5 Democracy and Sustainability: Aspects of Efficiency, Legitimacy and Integration

Nicos Labaras

6 Democracy, Justice and Risk Society: the Meaning and Shape of Ecological Democracy

Wouter Achterberg

\section{Part III Rights}

7 Constitutional Environmental Rights and Liberal Democracy Tim Hayward

8 Privatizing Genetic Resources: Biodiversity, Communities and Intellectual Property Rights

Markku Oksanen

9 Sustainability, Global Warming, Population Policies and Liberal Democracy

Robin Attfield 
vi Contents

\section{Part IV Duties}

10 The Duties of Being and Association Mike Mills

11 Virtue, Sustainability and Liberal Values

Ludvig Beckman

12 Sustainability and the Limits of Liberalism

Marcel Wissenburg

13 Conclusion

John Barry, Marcel Wissenburg and Marius de Geus

Bibliography

Index 


\title{
Foreword
}

\author{
Andrew Dobson
}

Ten years ago, Mark Sagoff asked whether environmentalists could be liberals (Sagoff, 1988, pp. 146-70). At the time, this seemed an odd question to ask - not because it lacked intrinsic interest, but because the politically important relationships seemed to be between environmentalism and socialism, or environmentalism and feminism, rather than between environmentalism and liberalism. Sagoff should now be congratulated for his foresight, however, because the increasing dominance of the liberal worldview in academic and political life makes it imperative that environmentalists (or the environmental agenda more broadly) are brought into contact with it. In recent years a number of people have explored the relationship between liberalism and environmentalism (Hayward, 1995; Eckersley, 1996; Wissenburg, 1998; Barry, 1999; Miller, 1999, for example), and in one way or another each of the chapters in this book deals with it too - in a manner that reveals both the tensions created and the opportunities presented by the possibility of a liberal environmentalism, or an environmentally sensitive liberalism.

On the face of it, liberal and environmental impulses are as opposed as it is politically possible to be, with liberalism's individualism, its endorsement of private acquisition, its support for limited government, its lauding of the market as an efficient and equitable distributor of resources, and its opposition to state support for definitive versions of 'the good life', all called into question by the environmentalist agenda. In the name of the overweaning value of autonomy, liberals will resist environmentalist attempts to alter individual tastes or preferences, and in the tradition of Kant and Locke they will insist on the kind of strict value demarcation between human beings and other animals that environmentalists have tried to undermine.

But liberalism is tremendously elastic, and it has plenty of intellectual resources that can be deployed in an environment-friendly fashion. Liberal environmentalists will argue, for example, that while political institutions should indeed be neutral in respect of the good, citizens themselves are perfectly entitled to argue ethical preferences in the way environmentalists would like. Indeed, liberals may suggest that only in the tolerant liberal polity will environmentalists get the air-time they so crave. Similarly, while Kant and Locke are indeed part 
of the liberal heritage, so are Jeremy Bentham and John Stuart Mill, and these latter two will answer the question 'What faculty, X, must beings possess to be entitled to moral considerability?' in a very different way to the former two - in a way, indeed, that will bring a smile to the faces of environmentalists. Perhaps most importantly, the liberal language of rights can be deployed for ends that will further gladden environmentalist hearts. The possibility of rights for animals is much discussed, for example, and there have been attempts to push rightstalk into ever more exotic areas of the non-human natural world. Even more significant, maybe, is the idea of rights for future generations, since this ties the environmental and liberal agendas tight together. This might not be immediately apparent, but once we realize that 'the environment' is one of the things we hand on to future generations, and if we accept that future generations have a right to a sustainable and satisfying environment, then future generation rights and environmental sustainability can be seen to be intimately linked. As Hayward astutely points out: 'In talking about rights of future generations, one is already addressing matters of environmental concern' (Hayward, 1994, p. 142).

Perhaps, though, this is just the point at which liberalism and environmentalism come unstuck. In his path-breaking analysis of the relationship between the two, Marcel Wissenburg, one of the editors of the present book, writes that:

We may also expect the introduction of the notion of limits to growth and resources, and with it that of sustainability, to lead to questions of a substantive normative nature. A sustainable society need not be one big Yellowstone Park - we can imagine a worldwide version of Holland stuffed with cows, grain and greenhouses, or even a global Manhattan without the Park to be as sustainable and for many among us as pleasant as the first. Hence a greener liberalism will have to define more clearly what kind of sustainability, what kind of world, it aims for.

(Wissenburg, 1998, p. 81)

I think Wissenburg is right about this, and if he is, then his 'greener liberalism' will be obliged to develop a moral conception of our relationship with the non-human natural world in the context of deciding what kind of world we want to hand on to future generations. On this account, environmental sustainability necessarily raises questions regarding the good life, and so liberalism's endorsing of the objective of environmental sustainability commits it to a definitive moral conception 
of 'people's appropriate relation to nature' (in Sagoff's words, 1988, p. 150). If this is a pill that liberalism cannot swallow - as I suspect it cannot - then this may be where liberalism and ecologism finally part company.

Andrew Dobson

School of Politics, International Relations

and the Environment,

Keele University, UK 
This page intentionally left blank 


\section{The Contributors}

Wouter Achterberg is Senior Lecturer in Environmental Philosophy, Ethics and Political Philosophy at the University of Amsterdam, the Netherlands, and Professor in Humanistic Philosophy at Wageningen University, Wageningen, the Netherlands.

Robin Attfield is Professor of Philosophy at Cardiff University, Wales.

John Barry is Reader in the School of Politics, The Queen's University of Belfast, Northern Ireland.

Ludvig Beckman is a PhD student at the Department of Government, Uppsala University, Sweden.

Marius de Geus is Lecturer in Political Theory and Legal Philosophy at the University of Leiden, the Netherlands.

Tim Hayward is Senior Lecturer in the Department of Politics, University of Edinburgh, Scotland.

Nicos Labaras is a PhD student in the Department of Politics, University of Edinburgh, Scotland.

Mike Mills is Senior Lecturer in the Department of Politics and Modern History at London Guildhall University, London, England.

Markku Oksanen is Research Fellow of the Academy of Finland, based at the Department of Philosophy of the University of Turku, Finland.

Gayil Talshir is Lecturer in the Department of Politics at the Hebrew University of Jerusalem, Israel.

Marcel Wissenburg is Lecturer in the School of Public Affairs and staff member of the Nijmegen Centre for Business, Environment and Government (NICE) at the University of Nijmegen, the Netherlands. 